Original Article

\title{
Anesthetic toxic isoflurane and health risk assessment in the operation room in Abadan, Iran during 2018
}

\author{
Arghavan Afra ${ }^{\mathrm{a}}$, Maziyar Mollaei Pardeh ${ }^{\mathrm{b}}$, Hamed Saki ${ }^{\mathrm{c}}$, Majid Farhadi ${ }^{\mathrm{d}}$, Sahar Geravandi ${ }^{\mathrm{e}}$, \\ Pouria Mehrabi $^{\mathrm{a}}$, Sina Dobaradaran ${ }^{\mathrm{f}}$, Mahboobeh Momtazan ${ }^{\mathrm{a}}$, Zohreh Dehkordi ${ }^{\mathrm{g}}$, \\ Mohammad Javad Mohammadi ${ }^{\text {h,* }}$ \\ ${ }^{a}$ Abadan School of Medical Sciences, Abadan, Iran \\ ${ }^{\mathrm{b}}$ MSc of Epidemiology, Shahid Beheshti University of Medical Sciences, Tehran, Iran \\ ${ }^{\mathrm{c}}$ Department of Environmental Health Engineering, School of Public Health, Ahvaz Jundishapur University of Medical Sciences, Ahvaz, Iran \\ ${ }^{\mathrm{d}}$ Social Determinants Health Research Center, Department of Environmental Health, School of Health and Nutrition, Lorestan University of Medical Sciences, \\ Khorramabad, Iran \\ ${ }^{\mathrm{e}}$ Asadabad School of Medical Sciences, Asadabad, Iran \\ ${ }_{\mathrm{f}}^{\mathrm{f}}$ Department of Environmental Health Engineering, Faculty of Health, Bushehr University of Medical Sciences, Bushehr, Iran \\ ${ }^{\mathrm{g}}$ Razi Teaching hospital, Ahvaz Jundishapur University of Medical Sciences, Ahvaz, Iran \\ ${ }^{\mathrm{h}}$ Department of Environmental Health Engineering, School of Public Health AND Environmental Technologies Research Center (ETRC), Ahvaz Jundishapur University of \\ Medical Sciences, Ahvaz, Iran
}

\section{A R T I C L E I N F O}

\section{Keywords:}

Isoflurane

Operating room

Health risk assessment

Indoor air quality

Iran

\begin{abstract}
A B S T R A C T
Introduction: Anesthetic gases are very important for health among health care worker (HCWs) and patients in medical centers. Operating rooms (ORs) is the most important ward that use anesthetic gases. Isoflurane gases is very dangerous for HCWs.

Objective: In this study, we have associated the concentration of anesthetic toxic isoflurane gases (ppm) and the health risk assessment due to exposure to common anesthetic gases in Valiasr and Shahid Beheshti teaching hospital operating room during 2018.

Methods: In this study, we used the active sampling system by portable pump SKC and tubes (sorbent Tube Tenax TA $250 \mathrm{mg}$ ) for detection of isoflurane concentration (ppm). Different points of the operating rooms were selected for sampling. Hazard index (HI) quantified by calculating the non-cancer causing anesthetic toxic isoflurane gases.

Results: According result this study, the Valiasr and Shahid Beheshti had the lowest and the highest level of isoflurane. Based on result this study, level of isoflurane on indoor air quality in the operation room in Valiasr and Shahid Beheshti hospital were 2.129 and $2.436 \mathrm{ppm}$, respectively. According to the results from the current study, hazard index was under 1.0 and it amount showed that no significant risk of adverse health endpoint attributed to exposure to level of isoflurane in Valiasr and Shahid Beheshti teaching hospital operating room during 2018.

Conclusion: According Result this study the average concentration of isoflurane and the health risk assessment in Valiasr and Shahid Beheshti teaching hospital operating room during 2018 because of flaw in the ventilation system was significantly higher than standard.
\end{abstract}

\section{Introduction}

Anesthetic gases (AG) is one of the most important indoor air quality (IAQ) that increase the risk of genetic damage, respiratory and renal disease among exposed health care worker (HCWs) and patients in operating rooms (ORs). ${ }^{1-8}$ The main please that used to anesthetics are dental offices, veterinary hospitals and operating rooms. ${ }^{9-11}$ Based on report International Agency for Research on Cancer (IARC) states in humans there is inadequate evidence for the carcinogenicity of isoflurane, sevoflurane, nitrous oxide and halothane. ${ }^{11-14}$ According to result different study hundreds of patients and surgical staff in operating rooms have suffered from anesthetic gases. ${ }^{4,12,15-17}$

\footnotetext{
*Corresponding author. Tel.: +98 9355439707; fax: +98 6153384020 .

E-mail addresses: javad.sam200@gmail.com, Mohamadi.m@ajums.ac.ir (M.J. Mohammadi).
} 
Isoflurane is the most commonly anesthetic gases that consumed in operating rooms medical centers. ${ }^{11,12}$ Isoflurane molecular formula is $\left(\mathrm{C}_{3} \mathrm{H}_{2} \mathrm{OClF}_{5}\right)$ and characteristics this gas include mild ethereal and solubility and colorless. ${ }^{11,18}$ Several study demonstrate the concerning effects of inhalation of volatile anesthetics gases especially isoflurane on human health. ${ }^{11,19,20}$ dryness and irritation of skin, liver and kidney damage, headaches, dizziness, drowsiness, redness in eyes, irritation of the mouth and increase the rate of morbidity on staffs ORs are the most health endpoint of isoflurane. ${ }^{4,11,12,21,22}$

One of the most important methods in contributing to infection control (reducing the number of surgical site infections (SSIs)) on patients and surgical staff safety and treatment anesthetic gases is Air conditioning systems.1-3, ${ }^{, 11}, 23-25$ Standards and guidelines for the air quality in ORs have been proposed, focusing on general OR ventilation requirements. ${ }^{1,26,27}$ In 2015 Joksovic et al. studied the early exposure to general anesthesia with isoflurane. ${ }^{9}$ An investigation Chaoul et al. measurement the concentration of anesthetic gases in operating rooms. ${ }^{28}$ Guirguis et al. in Ontario hospital personnel studied the health endpoint of exposure to anesthetic gases among health care worker. ${ }^{29}$ In similar work, Gupta et al. had shown a determined does exposure to inhalation anesthesia in operating rooms. ${ }^{30}$

Abadan and Khorramshahr are two most important cities in Khuzestan province that every year a large number of patients are treated in hospitals in these two cities. The purpose of this study was to measurement and the health risk assessment of isoflurane gases in the operation room at Valiasr and Shahid Beheshti educational hospitals in Abadan and Khorramshahr (located in south-western Iran), during year 2018.

\section{Methods}

\subsection{The study area}

The study area was Abadan $\left(30^{\circ} 20^{\prime} \mathrm{N}, 48^{\circ} 17^{\prime} \mathrm{E}\right)$ and Khorramshahr $\left(30^{\circ} 26^{\prime} \mathrm{N}, 48^{\circ} 11^{\prime} \mathrm{E}\right)$, located in southwest of Iran accounting 470,000 inhabitants (Fig. 1). ${ }^{31,32}$ Sites included in the study are recognized for Valiasr and Shahid Beheshti teaching hospital (Fig. 1). Shahid Beheshti and Valiasr teaching hospitals operating room are a tertiary-care hospital with 220 and 240 beds.

\subsection{Sampling and preparation}

This cross-sectional study was conducted in 8 operating rooms in Valiasr and Shahid Beheshti teaching hospital during 2018. In our study, an active sampling system was used to measuring the concentration of anesthetic toxic isoflurane gases (ppm) and the health risk assessment due to exposure to common anesthetic gases in the study area.

Active sampling system was implemented to measure the concentration of anesthetic gases isoflurane. In this study, selected different points of the operating rooms included; the anesthesiologist's breathing zone, the surgeon's breathing zone and the farthest corner room. SKC pump (Dorset, England) was equipped with sorbent tube (Tenax TA $250 \mathrm{mg}$ ) were used for measuring the level of isoflurane. ${ }^{33}$ Schematic of the sampling tube use in this study for gathered isoflurane showed in Fig. 2. Air sampling was done for $8 \mathrm{~h}$. Sorbent tube broken before the sampling and used with continuous flow pump. ${ }^{34}$ Air volume and sampling rate were $12 \mathrm{~L}$ at $0.05 \mathrm{~L} / \mathrm{min}$, respectively. Isoflurane was measurement based on standard of US National Institute for Occupational Safety and Health (NIOSH). ${ }^{5,35,36}$ for avoid gas escaping trapped in the sorbent the sampling tube was sealed immediately with plastic end caps. Then working analytical standards by injecting microliter amounts of concentrated stock standards into $2 \mathrm{~mL}$ vials containing $1.0 \mathrm{~mL}$ of desorption solvent delivered from the same dispenser used to desorb samples. Finally, Samples are desorbed with $\mathrm{CS}_{2}$ and concentration of isoflurane analyzed by Gas Chromatograph (GC) with a Flame Ionization Detector (FID). ${ }^{37,38}$

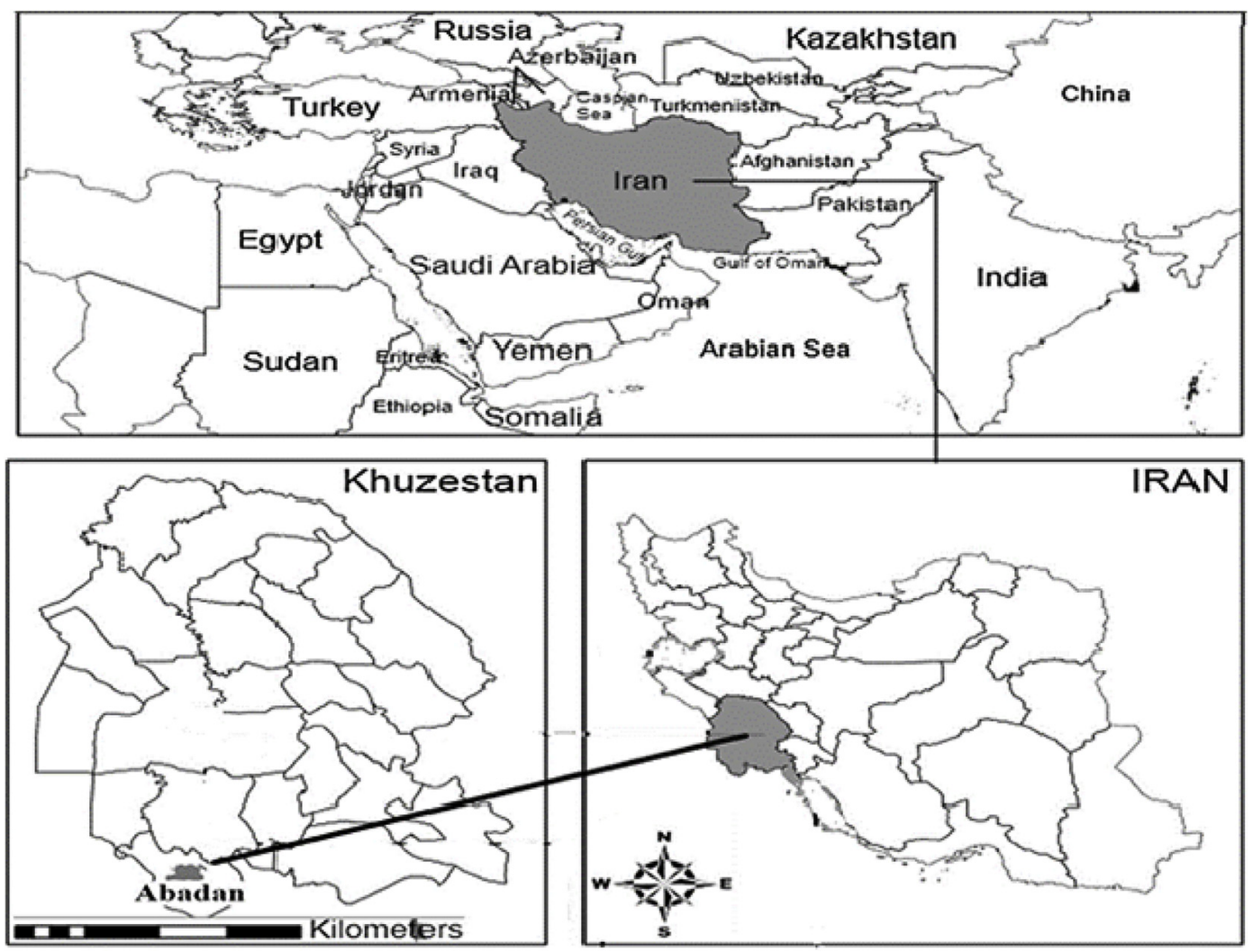

Fig. 1. Location of study area. 

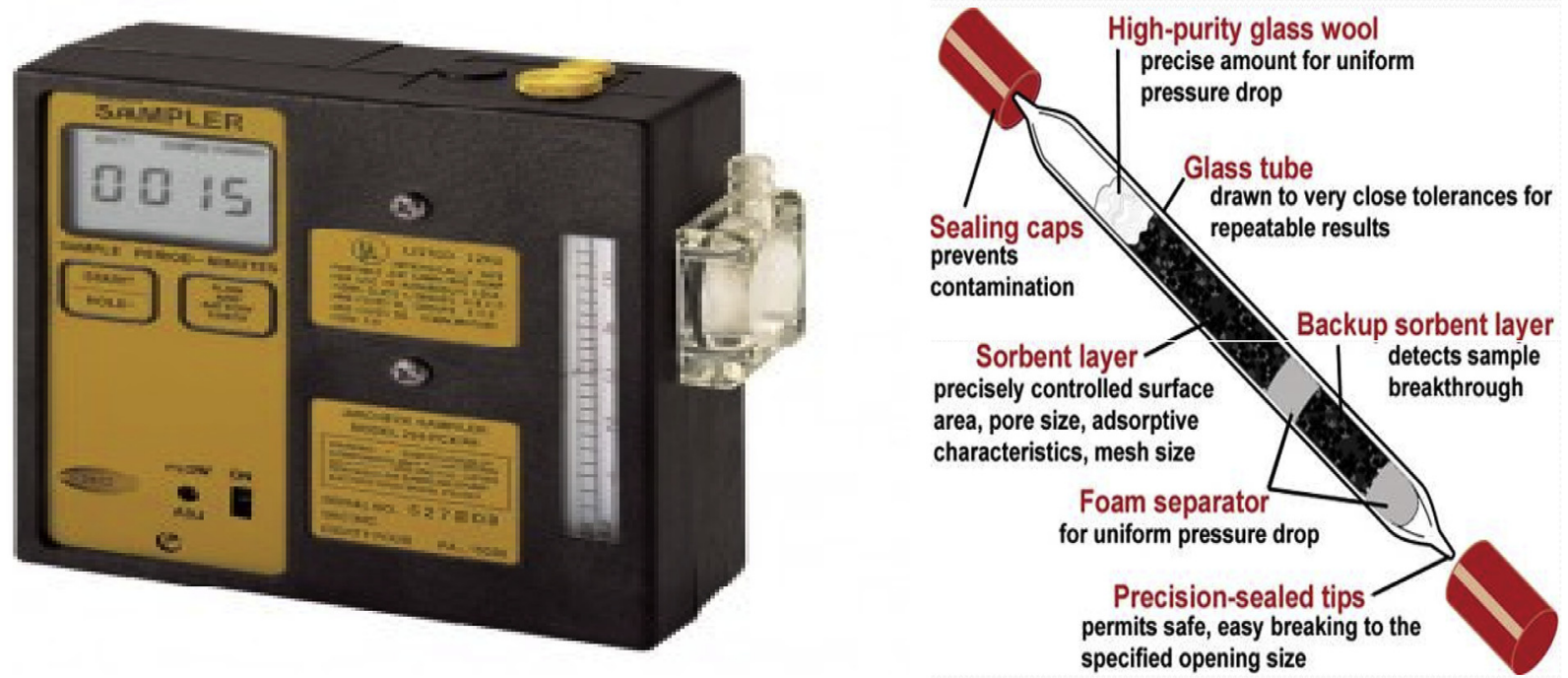

Fig. 2. Schematic of the sampling tube use in this study.

\subsection{GC-MASS analysis}

The analysis was performed by GC-MS. Anesthetic toxic isoflurane gases were analyzed using GC- MS (7890 N, AGILENT \& MS 5975C, MODE, EI). A fused silica capillary column (DB5-MS column $30 \mathrm{~m} \times 0.32 \mathrm{~mm} \times 0.5 \mu \mathrm{m}$ ) was used for separation. The injected volume of isoflurane gases was $3 \mu \mathrm{L} /$ splitless. Injector temperature program was initial $40{ }^{\circ} \mathrm{C}(2 \mathrm{~min})$, then ramp to $150^{\circ} \mathrm{C}$, at rate of $11^{\circ} \mathrm{C}$ per min, then, column temperature was increased to $194^{\circ} \mathrm{C}$ within 6 min. Helium was used as carrier gas at $2 \mathrm{~mL} / \mathrm{min}$. Flow rate and Auxiliary (transfer line) were $1.2 \mathrm{ml} / \mathrm{min}$ and $250-300^{\circ} \mathrm{C}$, respectively. One $\mathrm{ml}$ portions of vial headspace were injected into GC-MS system, while air samples of operating rooms were heated to $62{ }^{\circ} \mathrm{C}$ for $2 \mathrm{~min}$, and then were analyzed by injecting $1 \mathrm{ml}$ of vial head space into GC-MS system. In this study the method validation in analysis isoflurane samples were the limit of quantification (LOQ), the determination of the limit of detection (LOD), precision, matrix effect, accuracy, recovery, and calibration curve. LOD and LOQ of isoflurane were calculated by measuring the signal-to-noise ratios of 0.2 and $1.1 \mathrm{ng} / \mathrm{mL}$, respectively.

\subsection{Health risk assessment}

The potential health risk due to human exposure to an isoflurane was calculated according to NIOSH standard. The health hazard caused by isoflurane can be caused by ingestion, respiration of contaminated air, and skin contaminants with isoflurane. In order to A time weight average (TWA-8Hour) value is based on an employee's average airborne exposure in any 8-h per day, work shift. The time weighted average concentration is calculated using the following equation:

$E=\frac{C_{a} T_{a}+\ldots \ldots C_{n} T_{n}}{480 \min }$

where; $\mathrm{E}$ is the exposure for the working shift, $\mathrm{C}$ is the concentration during any period of time $\mathrm{T}$ where the concentration remains constant (ppm) and $\mathrm{T}$ is the duration in minutes of the exposure at the concentration $\mathrm{C}$ ( $\mathrm{min})$.

The level of human exposure resulting from isoflurane gas exposure can be expressed by an estimation of the average daily dose calculated using the following equation:

Average Daily Dose $(\mathrm{ADD})(\mathrm{mg} / \mathrm{kg}-$ day $)=\frac{H B \times C \times(M W)}{24.45 \times(B W)}$

where: $\mathrm{C}$ is time weighted average $\left(\mathrm{mg} / \mathrm{m}^{3}\right)$, MW is molecular weight of isoflurane or 200.055, HB is human breathing/day of air $\left(=20 \mathrm{~m}^{3}\right.$ in this study) and BW is body weight ( $\mathrm{kg})$ ( $=70 \mathrm{~kg}$ in this study). ${ }^{39}$

After reviewing several studies, an overall LOAEL can be determined at $150 \mathrm{ppm}$ of isoflurane at continuous exposure for 30 days, which resulted in depressed body weight. ${ }^{40}$ Reference Dose (RfD) in $\mathrm{mg} / \mathrm{m}^{3}$ values were calculated using the following equation:

Average Daily Dose (ADD) $(\mathrm{mg} / \mathrm{kg}-$ day $)=\frac{C \times M W \times(B R)}{24.45 \times B W \times(U F)}$

where: $\mathrm{C}$ is Time weighted average ((ppm)), MW is molecular weight of isoflurane or 200.055, BR is breathing rate of species $\left(=20 \mathrm{~m}^{3}\right.$ in this study), BW is species average body weight $(\mathrm{kg})(=70 \mathrm{~kg}$ for an adult in this study) and UF is uncertainty factors (factors of 10 in this study). ${ }^{41}$

Hazard index (HI) is a ratio of the exposure divided by the Reference Dose (RfD). Once the ADD and RfD are calculated, the hazard index was determined by the following equation:

Hazard Index $=\frac{A D D_{n}}{R f D}$

where: ADD is Average Daily Dose (mg/kg-day), and RfD is Reference dose ( $\mathrm{mg} / \mathrm{kg}$-day).

If $\mathrm{HI}$ is equal to or greater than one, indicates that adverse health effects will potentially be observed.

\subsection{Statistical analysis}

The coded data were entered in SPSS software version 16. Data analyses were conducted by reporting the descriptive statistics (frequency, mean, standard deviation) for each variable.

\subsection{Ethical considerations}

The exact approval number is IR.ABADANUMS.REC. 1396.218 and the ways of gathering patient data was only on the basis of the number of hospital admissions for cardiovascular diseases. Additionally, the ethical issues (including plagiarism, informed consent, misconduct, data fabrication and/or falsification, double publication and/or submission, redundancy, etc.) have been completely observed by the authors.

\section{Results}

This study was conducted in 8 operating rooms in Valiasr and Shahid Beheshti teaching hospital Abadan school of Medical Sciences, Iran during 2018. Based on the results, $50 \%$ of the rooms had exhaust 
Table 1

Isoflurane concentrations in Valiasr and Shahid Beheshti educational hospitals during 2018.

\begin{tabular}{lllll}
\hline $\begin{array}{l}\text { Operation room at } \\
\text { hospital }\end{array}$ & $\begin{array}{l}\text { NIOSH standard } \\
(\mathrm{ppm})\end{array}$ & $\begin{array}{l}\text { Average } \\
(\mathrm{ppm})\end{array}$ & Min (ppm) & $\begin{array}{l}\text { Max } \\
(\mathrm{ppm})\end{array}$ \\
\hline Valiasr & 2 & 2.129 & 0.285 & 2.743 \\
Shahid Beheshti & 2 & 2.436 & 0.394 & 3.264 \\
\hline
\end{tabular}

systems. There was the cooler was working at $100 \%$ of them. 12 samples were taken from operating rooms in the hospitals of study. The time weighted average concentrations (TWA \pm SD) in two main educational hospitals were calculated using equation (1). The standard of isoflurane according to US NIOSH and California OSHA (OSHA 5155 Table AC-1) permissible exposure limits for chemical contaminants is $2 \mathrm{ppm}\left(2000 \mathrm{mg} / \mathrm{m}^{3}\right){ }^{42,43}$

Based on the result Table 1, Valiasr and Shahid Beheshti had the highest and the lowest concentration of isoflurane during 2018. Also result showed that the annual average of isoflurane concentration in Valiasr and Shahid Beheshti educational hospitals operating room were higher than NIOSH (Table 1).

Table 2 showed calculated the average daily dose (ADD) and maximum daily. The ADD for Valiasr, educational hospital was $1.68 \mathrm{mg} / \mathrm{kg}$ day (Table 3). According result of Table 2 the maximum average daily dose for the Shahid Beheshti teaching hospital was $3.92 \mathrm{mg} / \mathrm{kg}$-day.

Health risk assessment due to ambient isoflurane gases, have been already investigated. Using the mice study's LOAEL of $150 \mathrm{ppm}$ isoflurane, the RfD was calculated to be $1.07 \mathrm{mg} / \mathrm{kg}$-day, accounting for three uncertainty factors. To calculate the HI the calculated human was selected due to the fact that the value does not include uncertainty factors regarding interspecies differences. The estimated hazard indices for Valiasr, educational hospital was 0.21 (Table 3). The hazard index for their maximum recorded exposure concentration was 0.28 (Table 3). Also, result showed that the hazard index for the Shahid Beheshti teaching hospital exposed to the average daily dose was 0.32 (Table 3).

Level of isoflurane are illustrating in Fig. 3 with three ranges (average, min and max) in the Valiasr and Shahid Beheshti teaching hospitals operating room.

\section{Discussion}

In this study, we measurement and the health risk assessment of isoflurane gases in the operation room at Valiasr and Shahid Beheshti educational hospitals in Abadan and Khorramshahr (located in southwestern Iran), during year 2018. According to the results of this study, between two main educational hospitals, Valiasr and Shahid Beheshti educational hospital operating room had the lowest and the highest level of isoflurane during 2018. Also, based on result our study the Valiasr and Shahid Beheshti had the highest and the lowest concentration of isoflurane. In 2010, Al- Ghanem et al. measurement level of anesthetic gases and effects on surgery staffs. ${ }^{44}$ They reported that health care worker was exposed to high concentrations of anesthetic gases. ${ }^{44}$ It should be noted that reasons this high exposed can be caused by mechanical, building and ventilation systems. In Germany Byhahn et al. studied the health effect attributed to exposure to anesthetics

Table 2

Average daily dose from Valiasr and Shahid Beheshti educational hospitals during 2018.

\begin{tabular}{lll}
\hline $\begin{array}{l}\text { Operation room at } \\
\text { hospital }\end{array}$ & $\begin{array}{l}\text { Average Daily Dose } \\
\left(\mathrm{mg} / \mathrm{m}^{3}\right)\end{array}$ & $\begin{array}{l}\text { Maximum Average Daily } \\
\text { Dose }\left(\mathrm{mg} / \mathrm{m}^{3}\right)\end{array}$ \\
\hline Valiasr & $1.68 \mathrm{mg} / \mathrm{kg}$-day & $\begin{array}{l}3.04 \mathrm{mg} / \mathrm{kg} \text {-day } \\
3.92 \mathrm{mg} / \mathrm{kg} \text {-day }\end{array}$ \\
\hline
\end{tabular}

Table 3

Hazard indices from Valiasr and Shahid Beheshti teaching hospital during 2018.

\begin{tabular}{lll}
\hline Operation room at hospital & $\begin{array}{l}\text { Hazard Index (using } \\
\text { ADD) }\end{array}$ & $\begin{array}{l}\text { Hazard Index (using Max } \\
\text { ADD) }\end{array}$ \\
\hline Valiasr & 0.21 & 0.28 \\
Shahid Beheshti & 0.32 & 0.41 \\
\hline
\end{tabular}

gases among staffs operation room. ${ }^{45}$ they reported that concentrations of anesthetics gases were lower than level of standard. ${ }^{45}$ In another study Gustorff et al. (2002) showed concentration of isoflurane is lower than recommended standard. ${ }^{46}$ In a similar study, Neisi et al. (2016) observed that there was a significant correlation between the risk of adverse health endpoint and level of isoflurane in Ahvaz. ${ }^{11}$

Mierdl et al. assessment of the relationship between occupational exposure to anesthetic gases and health endpoint. ${ }^{10}$ Result their study showed that at most times during the study level of anesthetic agents was low. ${ }^{10}$ Using the Human RfD of $22.02 \mathrm{mg} / \mathrm{kg}$-day, the hazard index for this risk assessment was calculated. The hazard index is defined as the ratio of the exposure concentration over the reference dose. If the hazard risk is greater than 1 , then adverse health effects are expected to occur. ${ }^{47}$ Based on the result in this study, the hazard indices for Valiasr and Shahid Beheshti teaching hospital during 2018 mean time weighted average (ADD $1.46 \mathrm{mg} / \mathrm{kg}$-day, $2.26 \mathrm{mg} / \mathrm{kg}$-day and $4.78 \mathrm{mg} / \mathrm{kg}$-day) and maximum (MAX $2.75 \mathrm{mg} / \mathrm{kg}$-day, $3.69 \mathrm{mg} / \mathrm{kg}$-day and $6.08 \mathrm{mg} / \mathrm{kg}$ day) concentrations were all under a risk ratio of 1.0, which confirms occupational exposure levels in these populations will not cause harmful health effects.

Results of our study showed that the isoflurane concentration was relatively higher because of the greater concentration in Valiasr and Shahid Beheshti educational hospital ORs. The reason this increase can be with old equipment, exhaust systems and defect in ventilation.

It be should note that no significant risk of adverse health effects because of the hazard risk ratio was under 1.0 and displays.

\section{Limitations and strengths}

Small sample in only two hospitals was the most limitations in this study. Finally, it should be noted that, similar studies should be carried out on other public and private hospitals, using large samples. Therefore, we measurement level of isoflurane and estimated outcomes attributed to them which may be under or overestimated. Also, medication protocol and education are the most important actions that can reduce the exposed to anesthetic gases isoflurane in operating rooms. Performed same comprehensive studies that covering all teaching and private hospitals in Iran.

\section{Conclusion}

In operating rooms isoflurane is one of the most important isomer on indoor air quality. In the present study, data analyzed showed that concentration of anesthetic toxic isoflurane gases (ppm) of air and the health risk assessment due to exposure to common anesthetic gases at Valiasr and Shahid Beheshti teaching hospitals operating room in Abadan and Khorramshahr (located in south-western Iran) during year 2018. Result showed that the annual average of isoflurane concentration in Valiasr and Shahid Beheshti educational hospitals operating room were higher than NIOSH. High concentration of this gas in ORs was associated with OR equipment's, building characterizes, ventilation, cooler and exhaust systems. To address this ORs problem, we recommend different plans such as further research for estimating the health effects of other types of anesthetic toxic gases, increasing operating room equipment, exhaust and cooler systems and improvement building characterizes. 


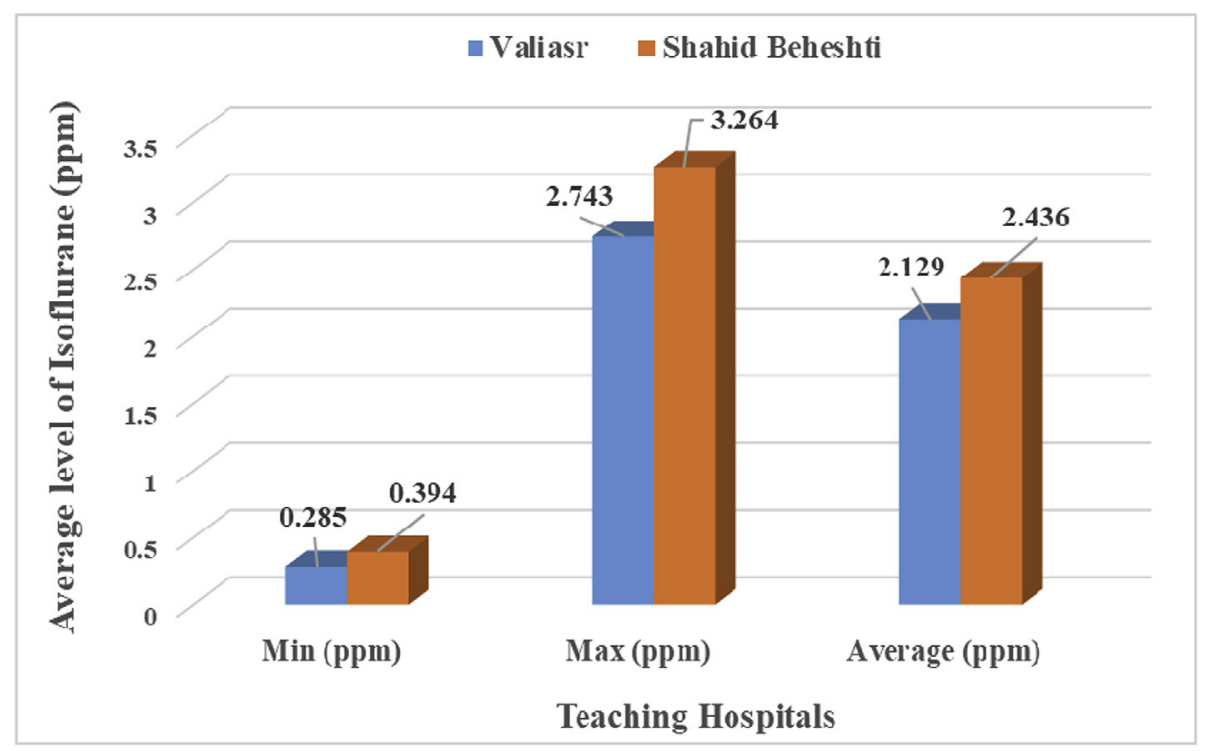

Fig. 3. Average level of isoflurane Measured in the Valiasr and Shahid Beheshti teaching hospitals operating room.

\section{Conflicts of interest}

Authors have no conflict of interests.

\section{Funding/support}

The authors gratefully acknowledge Abadan School of Medical Sciences for financial support and providing necessary facilities to accomplish thus research with project number of 96U-32. IR.ABADANUMS.REC.1396.218 in my article is ethical code that would cited in article.

\section{Acknowledgment}

The authors would like to thank at Abadan School of Medical Sciences for providing financial supports for this research by the grant: (IR.ABADANUMS.REC1396.218).

\section{Appendix A. Supplementary data}

Supplementary data to this article can be found online at https:// doi.org/10.1016/j.cegh.2019.08.008.

\section{References}

1. Choi DH, Choi SH, Kang DH. Influence of surgical smoke on indoor air quality in hospital operating rooms. Aerosol and Air Quality Research. 2017;1-10.

2. Huang P-Y, Shi Z-Y, Chen C-H, Den W, Huang H-M, Tsai J-J. Airborne and surfacebound microbial contamination in two intensive care units of a medical center in central Taiwan. Aerosol and Air Quality Research. 2013;13:1060-1069.

3. Chuaybamroong P, Choomseer P, Sribenjalux P. Comparison between hospital single air unit and central air unit for ventilation performances and airborne microbes. Aerosol Air Qual Res. 2008;8:28-36.

4. Byhahn C, Heller K, Lischke V, Westphal K. Surgeon's occupational exposure to nitrous oxide and sevoflurane during pediatric surgery. World J Surg. 2001;25:1109-1112.

5. Ghimenti S, Tabucchi S, Bellagambi FG, et al. Determination of sevoflurane and isopropyl alcohol in exhaled breath by thermal desorption gas chromatography-mass spectrometry for exposure assessment of hospital staff. J Pharm Biomed Anal. 2015;106:218-223.

6. Hoerauf K, Lierz M, Wiesner G, et al. Genetic damage in operating room personnel exposed to isoflurane and nitrous oxide. Occup Environ Med. 1999;56:433-437.

7. Neisi A, Albooghobeish M, Geravandi S, et al. Investigation of health risk assessment sevoflurane on indoor air quality in the operation room in Ahvaz city, Iran. Toxin Rev. 2018:1-9.

8. Nashibi R, Mohammadi MJ, Alavi SM, et al. Infection after open heart surgery in Golestan teaching hospital of Ahvaz. Iran. Data in brief. 2018;16:478-482.

9. Joksovic PM, Lunardi N, Jevtovic-Todorovic V, Todorovic SM. Early exposure to general anesthesia with isoflurane downregulates inhibitory synaptic neurotransmission in the rat thalamus. Mol Neurobiol. 2015;52:952-958.

10. Mierdl S, Byhahn C, Abdel-Rahman U, Matheis G, Westphal K. Occupational exposure to inhalational anesthetics during cardiac surgery on cardiopulmonary bypass. Ann Thorac Surg. 2003;75:1924-1927.

11. Neisi A, Albooghobeish M, Geravandi S, Mohammadi MJ, Torabpour M, Hashemzadeh B. Association of anesthetic toxic isoflurane gases of the indoor air of operating room, Ahvaz, Iran during 2016. Toxin Rev. 2017;36:141-146.

12. Kumar S, Tripathi M. An add-on advantage of isoflurane graphical monitoring: detection of intraoperative bronchospasm. Indian J Anesthesia. 2015;59:200.

13. Kanmura Y, Sakai J, Yoshinaka H, Shirao K. Causes of nitrous oxide contamination in operating rooms. Surv Anesthesiol. 2000;44:41.

14. Lachenmeier DW, Kanteres F, Rehm J. Carcinogenicity of acetaldehyde in alcoholic beverages: risk assessment outside ethanol metabolism. Addiction. 2009;104:533-550.

15. Macario A, Weinger M, Carney S, Kim A. Which clinical anesthesia outcomes are important to avoid? The perspective of patients. Anesth Analg. 1999;89:652.

16. Tait AR, Voepel-Lewis T, Malviya S. Do they understand?(Part II) Assent of children participating in clinical anesthesia and surgery research. Anesthesiology: J American Soc Anesthesiology. 2003;98:609-614.

17. Weber L, Yeomans DC, Tzabazis A. Opioid-induced hyperalgesia in clinical anesthesia practice: what has remained from theoretical concepts and experimental studies? Current Opinion in Anesthesiology. 2017;30:458-465

18. Devisscher L, Schauvliege S, Dewulf J, Gasthuys F. Romifidine as a constant rate infusion in isoflurane anaesthetized horses: a clinical study. Vet Anaesth Analg. 2010;37:425-433.

19. Bargellini A, Rovesti S, Barbieri A, et al. Effects of chronic exposure to anaesthetic gases on some immune parameters. Sci Total Environ. 2001;270:149-156.

20. Izdes S, Sardas S, Kadioglu E, Karakaya AE. DNA damage, glutathione, and total antioxidant capacity in anesthesia nurses. Arch Environ Occup Health 2010;65:211-217.

21. Raj N, Henderson K, Hall JE, et al. Evaluation of personal, environmental and biological exposure of paediatric anaesthetists to nitrous oxide and sevoflurane. Anaesthesia. 2003:58:630-636.

22. McGregor DG. Occupational exposure to trace concentrations of waste anesthetic gases. Mayo Clin Proc. 2000;75:273-277 Elsevier.

23. Mohammadi MJ, Albooghobeish M, Geravandi S, Valipour A, Karimyan A, Neisi A. Study of environmental factors in the operation rooms in Ahvaz. Fresenius Environ Bull. 2017;26:7432-7436.

24. World Health Organization G. WHO Guidelines for Safe Surgery. 2008; 2008

25. Weigelt JA, Lipsky BA, Tabak YP, Derby KG, Kim M, Gupta V. Surgical site infections: causative pathogens and associated outcomes. Am J Infect Contr. 2010;38:112-120.

26. Chow T-T, Wang J. Dynamic simulation on impact of surgeon bending movement on bacteria-carrying particles distribution in operating theatre. Build Environ. 2012;57:68-80.

27. Liu J, Wang H, Wen W. Numerical simulation on a horizontal airflow for airborne particles control in hospital operating room. Build Environ. 2009;44:2284-2289.

28. Chaoul MM, Braz JRC, Lucio LMC, Golim MA, Braz LG, Braz MG. Does occupational exposure to anesthetic gases lead to increase of pro-inflammatory cytokines? Inflamm Res. 2015;64:939-942.

29. Guirguis S, Pelmear P, Roy M, Wong L. Health effects associated with exposure to anaesthetic gases in Ontario hospital personnel. Br J Ind Med. 1990;47:490-497.

30. Gupta D, Mckelvey G, Kaminski E, Zestos MM. Does exposure to inhalation anesthesia gases change the ratio of X-bearing sperms and Y-bearing Sperms? A worth exploring project into an uncharted domain. Med Hypotheses. 2016;94:68-73.

31. Momtazan M, Geravandi S, Rastegarimehr B, et al. An investigation of particulate 
matter and relevant cardiovascular risks in Abadan and Khorramshahr in 2014-2016. Toxin Rev. 2018:1-8.

32. Mohammadi MJ, Ghazlavi E, Gamizji SR, et al. Data on evolutionary relationships between hearing reduction with history of disease and injuries among workers in Abadan Petroleum Refinery. Iran. Data in brief. 2018;16:817-821.

33. Tankó B, Molnár C, Budi T, Peto C, Novák L, Fülesdi B. The relative exposure of the operating room staff to sevoflurane during intracerebral surgery. Anesth Analg. 2009;109:1187-1192.

34. All D, Business S. OSHA Instruction CPL 2-2.60. Exposure Control Plan for Federal OSHA Personnel with Occupational Exposure to Bloodbome Pathogens. 1994; 1994.

35. Muir JL. Criteria for a Recommended Standard... Occupational Exposure to Waste Anesthetic Gases and Vapors. Elsevier (National Institute for Health for Occupational Safety and Health, Cincinnati); 1978:77-140.

36. Control CfD. NIOSH recommendations for occupational safety and health standards 1988. MMWR. Morbidity and mortality weekly report. 1988;37:1.

37. Kunze N, Weigel C, Vautz W, et al. Multi-capillary column-ion mobility spectrometry (MCC-IMS) as a new method for the quantification of occupational exposure to sevoflurane in anaesthesia workplaces: an observational feasibility study. J Occup Med Toxicol. 2015;10:1.

38. Herzog-Niescery J, Botteck NM, Vogelsang H, et al. Occupational chronic sevoflurane exposure in the everyday reality of the anesthesia workplace. Anesth Analg. 2015;121:1519-1528
39. Sakai EM, Connolly LA, Klauck JA. Inhalation anesthesiology and volatile liquid anesthetics: focus on isoflurane, desflurane, and sevoflurane. Pharmacotherapy. 2005;25:1773-1788.

40. Zhou X, Li W, Chen X, et al. Dose-dependent effects of sevoflurane exposure during early lifetime on apoptosis in hippocampus and neurocognitive outcomes in SpragueDawley rats. Int J Physiol Pathophysiol Pharmacol. 2016;8:111.

41. Suckow MA, Weisbroth SH, Franklin CL. The Laboratory Rat. Academic Press; 2005

42. Dascalaki EG, Lagoudi A, Balaras CA, Gaglia AG. Air quality in hospital operating rooms. Build Environ. 2008;43:1945-1952.

43. Checkai MJ. Risk assessment for occupational exposure to isoflurane in pharmaceutical research and veterinary facilities in san diego, California. A Thesis Presented to the Faculty of San Diego State University. 2014; 2014:1-42.

44. Al-Ghanem S, Battah AH, Salhab AS. Monitoring of volatile anesthetics in operating room personnel using GC-MS. Jordan Med J. 2010;42.

45. Byhahn C, Wilke H-J, Westphal K. Occupational exposure to volatile anaesthetics. CNS Drugs. 2001;15:197-215

46. Gustorff B, Lorenzl N, Aram L, Krenn CG, Jobst BP, Hoerauf KH. Environmental monitoring of sevoflurane and nitrous oxide using the cuffed oropharyngeal airway. Anesth Analg. 2002;94:1244-1248.

47. Lundgren RE, McMakin AH. Risk Communication: A Handbook for Communicating Environmental, Safety, and Health Risks. John Wiley \& Sons; 2013. 